\title{
RADICAL HOUSEWIVES
}

\author{
Price Wars and Food Politics in \\ Mid-Twentieth-Century Canada
}

Radical Housewives is a history of Canada's Housewives Consumers Association. This association was a community-based women's organization with ties to the communist and social democratic left that, from 1937 until the early 1950s, led a broadly based popular movement for state control of prices and made other far-reaching demands on the state. As radical consumer activists, the Housewives engaged in gender-transgressive political activism that challenged the government to protect consumers' interests rather than just those of business while popularizing socialist solutions to the economic crises of the Great Depression and the immediate postwar years.

Julie Guard's exhaustive research, including archival analysis and interviews with twelve former Housewives, recovers a history of women's social justice activism in an era often considered politically dormant and adds a Canadian dimension to the history of politicized consumerism and of politicized materialism. Radical Housewives reinterprets the view of postwar Canada as economically prosperous and reveals the left's role in the origins of the food security movement.

(Studies in Gender and History)

JULIE GUARD is an associate professor of labour studies at the University of Manitoba. 
STUDIES IN GENDER AND HISTORY

General Editors: Franca Iacovetta and Karen Dubinsky 


\title{
Radical Housewives
}

\section{Price Wars and Food Politics in Mid-Twentieth-Century Canada}

\author{
JULIE GUARD
}

UNIVERSITY OF TORONTO PRESS

Toronto Buffalo London 
(C) University of Toronto Press 2019

Toronto Buffalo London

utorontopress.com

Printed in Canada

ISBN 978-1-4875-0215-7 (cloth)

ISBN 978-1-4875-2181-3 (paper)

( Printed on acid-free, $100 \%$ post-consumer recycled

paper with vegetable-based inks.

Studies in Gender and History

\section{Library and Archives Canada Cataloguing in Publication}

Title: Radical housewives : price wars and food politics in mid-twentieth-century Canada / Julie Guard.

Names: Guard, Julie, 1952-, author.

Series: Studies in gender and history ; 47.

Description: Series statement: Studies in gender and history ; 47 |

Includes bibliographical references and index.

Identifiers: Canadiana 20190045647 | ISBN 9781487502157 (cloth) | ISBN 9781487521813 (paper)

Subjects: LCSH: Housewives Consumers Association - History -

20th century | LCSH: Consumer movements - Canada - History -

20th century. | LCSH: Housewives - Political activity - Canada - History -

20th century. | LCSH: Women - Political activity - Canada - History -

20th century. | LCSH: Food - Political aspects - Canada - History -

20th century. | LCSH: Cost and standard of living - Canada - History -

20th century. | LCSH: Price regulation - Canada - History - 20th century. |

LCSH: Social justice - Canada - History - 20th century.

Classification: LCC HC120.C63 G83 2019 | DDC 381.3/2097109045 - dc23

This book has been published with the help of a grant from the Federation

for the Humanities and Social Sciences, through the Awards to Scholarly

Publications Program, using funds provided by the Social Sciences and Humanities Research Council of Canada.

University of Toronto Press acknowledges the financial assistance to its publishing program of the Canada Council for the Arts and the Ontario Arts Council, an agency of the Government of Ontario.

Canada Council for the Arts
Conseil des Arts du Canada

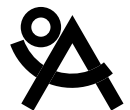

ONTARIO ARTS COUNCIL

CONSEIL DES ARTS DE L'ONTARIO

an Ontario government agency Un organisme du gouvernement de l'Ontario
Funded by the

Government of Canada

Financé par le gouvernement du Canada 